\title{
POTENSI TEPUNG DAUN ASHITABA (Angelica keskei) SEBAGAI SUMBER FITOBIOTIK DALAM PAKAN TERHADAP PERFORMA BURUNG PUYUH JANTAN Coturnix coturnix japonica FASE AKHIR (FINISHER)
}

\author{
1)Dina Oktaviana, ${ }^{2)}$ Supriadi, dan ${ }^{3)}$ Maratun Jannah \\ 1,2,3) Fakultas Kedokterhan Hewan, Program Studi Pendidikan Kedokteran Hewan, Universitas \\ Pendidikan Mandalika Mataram, Jalan Pemuda No. 59A. Mataram Tlp (0370 ) 632082 alamat email : \\ dinaoktaviana_2013@yahoo.com, email : supriadi.pkh10@gmail.com, email : \\ maratun.janah@yahoo.com
}

\begin{abstract}
Abstrak
Peningkatan potensi produksi burung puyuh memerlukan manajemen pemeliharaan yang baik, terutama pada pemilihan bahan pakan. Bahan pakan yang akan digunakan harus memiliki kandungan nutrient cukup untuk kebutuhan burung puyuh, dan dapat dijadikan sebagai salah satu sumber fitobiotik. Salah satu sumber atau bahan pakan yang dapat digunakan sebagai sumber fitobiotik adalah daun Ashitaba. Sebagai sumber fitobiotik Ashitaba (Angelica keiskei) merupakan tanaman multi fungsi karena kaya akan vitamin, mineral, asam amino, unsur mineral maupun zat aktif.Tujuan penelitian ini adalah untuk mengetahui performa burung puyuh jantan Coturnix coturnix japonica fase akhir (finisher) yang mendapatkan bahan pakan tambahan dalam susun ransumnya berupa tepung daun Ashitaba Angelica keskei. Penelitian ini menggunakan 5 macam perlakuan pakan yang berbeda dengan 4 kali ulangan sehingga 20 ekor burung puyuh jantan tersebar dalam 20 kandang unit percobaan. Lima macam perlakuan adalah P0 $=98 \%$ pakan basal, $2 \%$ filler, $0 \%$ tepung daun Ashitaba, $\mathrm{P} 1=98 \%$ pakan basal, $1,5 \%$ filler, $0,5 \%$ tepung daun Ashitaba, $\mathrm{P} 2=98 \%$ pakan basal, $1 \%$ filler, $1 \%$ tepung daun Ashitaba, P3 $=98 \%$ pakan basal, 0,5\% filler, 1,5\% tepung daun Ashitaba, P4 $=98 \%$ pakan basal, 0\% filler, $2 \%$ tepung daun Ashitaba. Parameter yang diuji dalam penelitian ini adalah: jumlah konsumsi pakan, pertambahan bobot badan, bobot potong serta konversi pakan (FCR)Semua data yang didapat dianalisis statistik dengan uji rancangan acak lengkap pola searah serta ragam annova melalui spss dan jika terdapat perbedaan diuji lanjut degan uji Duncan's. Berdasarkan analisis statistik menunjukkan bahawa pemberian tepung Ashitaba dalam ransum puyuh jantan tidak berpengaruh nyata terhadap jumlah konsumsi pakan dan pertambahan bobot badan, akan tetapi mampu meningkatkan bobot potong $\mathrm{P}>0,05$ dan menurunkan angka konversi pakan $\mathrm{P}>0.05$.
\end{abstract}

Kata Kunci: Burung Puyuh Jantan, Tepung Ashitaba, Jumlah Konsumsi Pakan, Pertambahan Bobot Badan, Bobot Potong dan Konversi Pakan.

\section{POTENTIAL OF ASHITABA LEAVES FLOUR (Angelica keskesi) AS A PHYTHOBIOTIC SOURCE FEED ON END STAGE PERFORMANCE OF MALE LAYING QUIL (Coturnixcoturnix japonica) FINAL PHASE (FINISHER)}

\begin{abstract}
Increasing potential for laying quil production requires good maintenance management, particularly in the selection of feeding ingredients. The feed ingredients should be containing sufficient nutrients for the requirements of the laying quil and can be utilized as a source of phytobiotics. One of the source of feeding ingredient that can be used as a source of phytobiotics is Ashitaba leaves. As a source of phytobiotics, Ashitaba (Angelica keskei) is multi-functional plant because it is rich in vitamins, minerals, amino acid, mineral elements and active substances. The aims of this research was to determine the performance of male laying quil (Coturnixcoturnix japonica) in the final phase (finisher) which obtained additional feed ingredients from the Ashitaba leaves flour. The Study have been utilized 5 different feed treatments with 4 replications so that 20 male laying quails were spread over 20 cages in the experimental unit. Five kinds of treatment were P0 $=98 \%$ basal feed, $2 \%$ filler, $0 \%$ Ashitaba leaf
\end{abstract}


Agrisaintifika

Jurnal Ilmu-Ilmu Pertanian

Vol. 4, No. 2, 2020

Oktaviana, et al. 2020

meal, $\mathrm{P} 1=98 \%$ basal feed, $1.5 \%$ filler, $0.5 \%$ Ashitaba leaf meal, $\mathrm{P} 2=98 \%$ basal feed, $1 \%$ filler, $1 \%$ Ashitaba leaf meal, P3 = 98\% basal feed, $0.5 \%$ filler, 1.5\% Ashitaba leaf meal, P4 = 98\% basal feed, $0 \%$ filler, $2 \%$ Ashitaba leaf flour. The parameters tested in this study were: total feed intake, body weight gain, cut weight and feed conversion rates (FCR) All data obtained were analyzed statistically by means of a completely randomized design test with one-way pattern and variance of annova through SPSS and if there were differences, then tested further with the test. Duncan's. Based on statistical analysis, it shows that giving Ashitaba flour in male quail rations has no significant effect on the amount of feed intake and body weight gain, but is able to increase cut weight $P>0.05$ and reduce the feed conversion rate $\mathrm{P}>0.05$

Key words : Male Laying Quil, Ashitaba leaves flour, Phytobiotics and performance.

\section{PENDAHULUAN}

\section{Puyuh (Coturnix coturnix} japonica) merupakan jenis burung yang tidak dapat terbang tinggi, ukuran relatif kecil dan berkaki pendek. Puyuh merupakan burung liar yang pertama kali diternakan di Amerika Serikat pada tahun 1870. Beberapa negara Eropa telah mengkonsumsi telur dan dagingnya karena puyuh bersifat dwiguna (Geofrin dkk, 2016). Selain sebagai ternak penghasil telur, burung puyuh juga dapat digunakan sebagai salah satu alternatif ternak pengahsil daging.

Keunggulan burung puyuh adalah cara pemeliharaan yang tidak sulit, cepat berproduksi, dan memiliki daya tahan tubuh yang tinggi terhadap penyakit. Selain diambil telurnya, daging puyuh merupakan makanan yang lezat dan bernilai gizi tinggi, kandungan gizi daging puyuh dalam 100 gram adalah lemak 14 gram, kolesterol 86 $\mathrm{mg}$, natrium $52 \mathrm{mg}$, kalium $216 \mathrm{mg}$, dan protein 25 gram serta mengandung kalsium vitamin A, D dan B12 (Maknun dkk, 2015)

Peningkatan potensi produksi burung puyuh memerlukan manajemen pemeliharaan yang lebih baik, terutama pada pemilihan bahan pakan. Bahan pakan yang akan digunakan harus memiliki kandungan nutrient cukup untuk kebutuhan burung puyuh, dan dapat dijadikan sebagai salah satu sumber fitobiotik. Fitobiotik (phytobiotic) adalah salah satu jenis fitokimia (phytochemicals) yang murni berasal dari tanaman (tumbuh-tumbuhan). Sebagai aditif, bahan ini dilaporkan mampu menstimulasi pertumbuhan dan sekaligus dapat dipergunakan untuk memelihara kesehatan unggas (Zuprizal, 2004). Pemanfaatan fitobiotik sebagai Natural Growth Promotor atau NGPs telah diidentifikasi sebagai alternatif yang efektif untuk antibiotik. Fitobiotik sebagai NGPs berkembang sebagai feed additive, immunitas, meningkatkan performa dan sangat efektif dalam meningkatkan kesehatan saluran pencernaan (Panda et al., 2009).

Salah satu sumber atau bahan yang dapat digunakan sebagai sumber fitobiotik adalah daun Ashitaba. Sebagai sumber fitobiotik Ashitaba (Angelica keiskei) merupakan tanaman multi fungsi karena kaya akan vitamin, mineral, asam amino, unsur mineral maupun zat aktif. Tanaman Ashitaba dapat digunakan sebagai sumber antioksidan terutama bagian daun karena mengandung senyawa kimia golongan alkoloid, saponin, glikosida, triterfenoid dan chalcone. Dalam chalcone terdapat dua senyawa flavonoid yaitu xantoangeol dan 4-hidrooxyricine. Senyawa inilah yang membedakan Ashitaba dengan tanaman sejenisnya 
Agrisaintifika

Jurnal Ilmu-Ilmu Pertanian

Vol. 4, No. 2, 2020

Oktaviana, et al. 2020

(Baba, 2009) senyawa ini memiliki struktur molekul yang aktif dan merupakan antioksidan yang sangat potensial dalam menangkap radikal bebas lebih tinggi. Senyawa chalcone ini mampu membersihkan darah, menekan sekresi asam, mencegah terbentuknya thrombus, antibakteri, mencegah kanker dan meningkatkan fungsi ginjal dalam membuang racun dari dalam darah secara efisien (Inamori, et al 1991)

Dilihat dari potensi daun Ashitaba sebagai sumber fitobiotik dalam pakan maka sangat baik untuk dilakukan sebuah penelitian guna meningkatkan produktivitas burung puyuh jantan sebagai salah satu alternatif ternak penghasil daging, sehingga salah satu produk pemenuhan kebutuhan protein hewani bagi masyarakat. Tujuan Penelitian ini yaitu untuk mengetahui performa burung puyuh jantan Coturnix coturnix japonica fase akhir (finisher) yang mendapatkan bahan pakan tambahan di dalam susun ransumnya berupa tepung daun Ashitaba Angelica keskei.

\section{METODE PENELITIAN waktu Penelitian}

Penelitian

dilaksanakan

padaBulan Juni Tanggal 7 sampai tanggal 21 tahun 2020 dikandang individu yang berada di Kelurahan Praya Kecamatan Praya Kabupaten Lombok Tengah ProvinsiNusa Tenggara Barat.

\section{Ternak}

Ternak yang digunakan dalam penelitian ini adalah burung puyuh jantan tipe petelur umur 4 minggu sebanyak 20 ekor.

Penelitiaan ini menggunakan rancangan acak lengkap (RAL) (Mattjik dan Sumertajaya, 2000), yang terdiri dari 5 perlakuan dan 4 ulangan, setiap ulangan terdiri dari 4 Burung Puyuh dengan rumus:

$$
\begin{array}{cl}
t(n-1) \geq 15 & \\
5 n-1 \geq 15 & n=\text { perlakuan } \\
5 n \geq 20 & \\
n=4 &
\end{array}
$$

keterangan :

Jumlah sampel $=20$ ekor (Sumber: Kusnaningrum, 2008)

\section{Alat Penelitian}

Selama pemeliharaan burung puyuh menggunakan kandang individu ukuran (40 $x 40) \mathrm{cm}^{2}$ sebanyak 20 unit, tempat pakan berbentuk nampan, tempat minum berukuran 0,25 liter, termometer untuk mengukur temperatur, alat-alat sanitasi kandang, serta disinfektan. Timbangan yang digunakan adalah timbangan digital, berkapasitas $5 \mathrm{~kg}$ dengan kepekaan 20 gram, timbangan duduk kapasitas $1 \mathrm{~kg}$ dengan kepekaan 1 gram.

\section{Susunan Ransum}

Pakan basal yang digunakan dalam penelitian ini adalah pakan untuk puyuh petelur dengan kandungan nutrien sebagai berikut:

Tabel 2. Kandungan nutrien bahanpakan

\begin{tabular}{lcccccc}
\hline Bahan Pakan & ME (Kcal/kg) & PK (\%) & SK (\%) & LK(\%) & Ca(\%) & P (\%) \\
\hline TepungDaun Ashitaba $^{1}$ & 1452,58 & 25,43 & 14,74 & 4,03 & 2,07 & 0,344 \\
Pakan Basal $^{2}$ & 3000,00 & 21,00 & 6,00 & 7,00 & 3,30 & 0,80 \\
Filler & 0 & 0 & 0 & 0 & 0 & 0 \\
\hline
\end{tabular}

${ }^{1}$ Berdasarkan analisis di Laboratorium Biokimia Nutrisi Fakultas Peternakan UGM 2019

${ }^{2}$ Berdasarkan tabelkomposisipakan di label pakan basal untuk puyuh petelur 
Tabel 3. Susunan formulasi ransum

\begin{tabular}{cccccc}
\hline \multirow{2}{*}{ Bahan Pakan } & \multicolumn{5}{c}{ SuplementasiTepungDaunAshitaba (\%) } \\
\cline { 2 - 6 } & $\mathrm{PO}$ & $\mathrm{PI}$ & $\mathrm{P} 2$ & $\mathrm{P} 3$ & $\mathrm{P} 4$ \\
\hline TepungDaunAshitaba & 0,00 & 0,50 & 1,00 & 1,50 & 2,00 \\
Pakan Basal & 98,00 & 98,00 & 98,00 & 98,00 & 98,00 \\
Filler & 2,00 & 1,50 & 1,00 & 0,50 & 0,00 \\
TOTAL & 100 & 100 & 100 & 100 & 100 \\
\hline
\end{tabular}

\section{Persiapan}

Lantai dan dinding kandang yang digunakan dicuci dengan ditergen. Fumigasi kandang menggunakan cairandisinfektan (destan) untuk lantai dan dinding kandang. Fumigasi dilakukan 2 minggu sebelum burung puyuh dimasukkan.

Pengolahan Daun Ashitaba hanya dikeringkan dengan cara diangin-aginkan tidak dibawah sinar matahari lagsung, jika sudah kering ditumbuk dan diayak hingga halus, kadar air tepung daun Ashitaba max $10 \%$.

\section{Pengelompokan burung puyuh}

Dua puluh ekor burung puyuh ditempatkan pada 5 kelompok perlakuan pakan yang berbeda, setiap kelompok perlakuan pakan diberikan replikasi 4 kali. Pada penelitian ini, masing-masing kelompok diberikan 1 ekor, sehingga seluruh burung puyuh jantan tersebut terdistribusi secara merata pada 20 unit kandang (unit percobaan). Seluruh burung puyuh dipelihara selama 14 hari.

\section{Pemeliharaan}

Pemberian pakan dilakukan 2 kali sehari pada pagi pukul 07.00 dan sore hari pada pukul 16.00 , serta pemberian air minum secara ad libitum. Pakan yang diberikan dan sisa pakan dikoleksi dan ditimbang. Penimbangan bobot badan burung puyuh dilakukan seminggu sekali.

Ternak yang digunakan dalam penilitian ini adalah burung puyuh jantan umur 4 minggu sebanyak 20 ekor dengan strain bibit Blester Blitar Jawa Timur.

\section{Metode Penelitian Performa Burung Puyuh}

Konsumsi pakan diketahui dari selisih bobot pakan yang diberikan dengan sisa pakan setiap hari dari masing-masing kandang (ulangan), selanjutnya dilakukan penghitungan penghitungan konsumsi pakan setiap kandang perminggu dan pada akhir penelitian dilakukan penghitungan konsumsi pakan kumulatif pada ulangan.

\section{Pertambahan bobot badan}

Penimbangan bobot badan burung puyuh jantan dimulai pada awal penelitian pada masing-masing ulangan, kemudian setiap minggu dilaksanakan penimbangan pada waktu yang telah ditentukan sampai akhir penelitian. Data pertambahan bobot badan selama penelitian diperoleh dari selisih antara bobot badan akhir dengan bobot badan awal. Bobot potong burung puyuh didapatkan dari bobot badan burung puyuh yang telah dipuasakan selam 8 sampai 12 jam, kemudian ditimbang.

\section{Konversi pakan}

Konversi pakan diperoleh dari pembagian antara jumlah pakan yang dikonsumsi dengan pertambahan bobot badan dalam satuan bobot dan waktu yang sama. 
Agrisaintifika

Jurnal Ilmu-Ilmu Pertanian

Vol. 4, No. 2, 2020

Oktaviana, et al. 2020

\section{HASIL DAN PEMBAHASAN}

\section{Performa Burung Puyuh}

Performa burung puyuh jantan

\section{Analisis Data}

Semua data hasil penelitian akan diuji secara statistik menggunakan rancangan acak lengkap pola searah (ragam ANNOVA melalui SPSS). Perbedaan ratarata antar perlakuan diuji lanjut dengan ujiDuncan's menurut Steel dan Torrie (1993).
Coturnix coturnix japonica fase finisher yang dipelihara selama dua minggu dilakukan pada empat parameter yaitu : Jumlah konsumsi pakan, pertambahan bobot badan, bobot potong dan konversi pakan (FCR). Berdasarkan analisis statistik maka didapatkan hasil penelitian sebagai berikut.

Tabel 4.1 Jumlah Konsumsi pakan (gram) burung puyuh jantan umur 4 sampai dengan 6 minggu yang diberikan pakan tambahan Tepung Daun Ashitaba

\begin{tabular}{|c|c|c|}
\hline \multirow{2}{*}{ No. } & \multicolumn{2}{|c|}{ Jumlah Konsumsi Pakan (gram) ${ }^{\text {ns }}$} \\
\hline & Perlakuan & Mean \pm Std Deviasi \\
\hline 1. & P0 & $225,75 \pm 11,20$ \\
\hline 2. & P1 & $224,75 \pm 1,89$ \\
\hline 3. & $\mathrm{P} 2$ & $225,75 \pm 6,34$ \\
\hline 4. & P3 & $224,25 \pm 4,03$ \\
\hline 5. & $\mathrm{P} 4$ & $220,75 \pm 2,21$ \\
\hline
\end{tabular}

Hasil penelitian menunjukkan bahwa penambahan Tepung Daun Ashitaba sampai dengan level $2,0 \%$ tidak berpengaruh nyata terhadap konsumsi pakan. Hal ini disebabkan karena imbangan energi dan protein dalam pakan relatif sama (iso energi dan iso protein) sehingga konsumsi pakan menjadi sama. Konsumsi pakan pada penelitian ini berkisar antara 220,75 gram sampai dengan 225,75 gram. Tingkat energi dalam pakan akan menentukan jumlah pakan yang dikonsumsi (Razak, 2016). Wahju (1997) menyatakan bahwa konsumsi pakan dapat dipengaruhi oleh banyak faktor yaitu strain, umur unggas, pakan yang diberikan, penyakit dan temperatur lingkungan, karena strain, umur dan pakan yang diberikan relatif sama maka jumlah konsumsi pakan puyuh jantan pun tidak berbeda secara nyata, hakekatnya ternak mengkonsumsi ransum untuk memenuhi kebutuhan energi dalam tubuh. Menurut Pond et al, 1995 yang dikutip (Manafe, 2017) bahwa palatabilitas pakan merupakan daya Tarik pakan atau bahan pakan yang dapat menimbulkan selera makan ternak. Hubungan pakan dan palatabilitas dapat dipengaruhi oleh beberapa factor yaitu rasa, bau dan warna bahan pakan. Anggorodi (1994) menyatakan bahwa konsumsi pakan adalah banyaknya makanan yang dimakan seekor ternak dalam 1 hari atau selisih antara jumlah makanan yang diberikan dengan jumlah makanan sisa selama 24 jam. Berdasarkan Tabel 4.2 menyatakan bahwa pertambahan bobot badan puyuh jantan yang diberikan bahan pakan tambahan berupa Tepung Daun Ashitaba tidak berpengaruh secara nyata pada pertambahan bobot badan. 
Agrisaintifika

Jurnal Ilmu-Ilmu Pertanian

Vol. 4, No. 2, 2020

Oktaviana, et al. 2020

Tabel 4.2 Pertambahan bobot badan (gram) burung puyuh jantan umur 4 sampai dengan 6 minggu yang diberikan pakan tambahan Tepung Daun Ashitaba

\begin{tabular}{|c|c|c|}
\hline \multirow{2}{*}{ No. } & \multicolumn{2}{|c|}{ Pertambahan Bobot Badan (gram) ${ }^{\text {ns }}$} \\
\hline & Perlakuan & Mean \pm Std Deviasi \\
\hline 1. & P0 & $51,75 \pm 2,62$ \\
\hline 2. & $\mathrm{P} 1$ & $43,50 \pm 7,85$ \\
\hline 3. & $\mathrm{P} 2$ & $47,25 \pm 15,25$ \\
\hline 4. & $\mathrm{P3}$ & $44,00 \pm 10,23$ \\
\hline 5. & $\mathrm{P} 4$ & $39,50 \pm 8,10$ \\
\hline
\end{tabular}

Bobot badan merupakan akumulasi hasil metabolisme. Hasil metabolisme didukung oleh banyaknya pakan yang dikonsumsi serta optimalisasi penggunaan pakan, karena dalam penelitian ini jumlah konsumsi pakan tidak berpengaruh secara nyata maka pertambahan badan puyuh jantan umur 4 sampai 6 minggu tidak berpengaruh nyata. Unggas membutuhkan asupan nutrisi yang cukup untuk meningkatkan bobot tubuhnya pada masa pertumbuhan. Salah satunya dengan meningkatkan konsumsi pakan. Kartadisastra (1997) yang dikutip oleh (Ratna, dkk, 2016) menyatakan bahwa bobot badan ternak senantiasa berbanding lurus dengan konsumsi ransum, makin tinggi bobot badannya, makin tinggi pula konsumsinya terhadap ransum. Rasyaf (2004) menyatakan bahwa faktor yang mempengaruhi bobot badan antara lain genetik, kesehatan, nilai gizi pakan, keseimbangan gizi pakan, keseimbangan zat pakan, stress dan lingkungan.

Tabel 4.3 Bobot Potong (gram) burung puyuh jantan umur 4 sampai dengan 6 minggu yang diberikan pakan tambahan Tepung Daun Ashitaba

\begin{tabular}{|c|c|c|}
\hline \multirow{2}{*}{ No. } & \multicolumn{2}{|c|}{ Bobot Potong (gram) } \\
\cline { 2 - 3 } & Perlakuan & Mean \pm Std Deviasi \\
\hline 1. & P0 & $133,75 \pm 3,30^{\mathrm{a}}$ \\
\hline 2. & P1 & $133,75 \pm 9,74^{\mathrm{a}}$ \\
\hline 3. & P2 & $134,00 \pm 13,29^{\mathrm{a}}$ \\
\hline 4. & P3 & $137,50 \pm 11,47^{\mathrm{a}}$ \\
\hline 5. & P4 & $152,25 \pm 6,89^{\mathrm{b}}$ \\
\hline
\end{tabular}

${ }^{*}=$ berbedanyata $(\mathrm{a}, \mathrm{b}$ superskrip yang berbeda pada kolom yang sama menunjukkan perbedaan yang nyata $\mathrm{P}>0,05)$

Tabel 4.4 Konversi Pakan burung puyuh jantan umur 4 sampai dengan 6 minggu yang diberikan pakan tambahan Tepung Daun Ashitaba

\begin{tabular}{|c|c|c|}
\hline \multirow{2}{*}{ No. } & \multicolumn{2}{|c|}{ Konversi Pakan $^{\star}$} \\
\cline { 2 - 3 } & Perlakuan & Mean \pm Std Deviasi \\
\hline 1. & P0 & $1,68 \pm 0,82^{\mathrm{a}}$ \\
\hline 2. & P1 & $1,68 \pm 0,11^{\mathrm{a}}$ \\
\hline 3. & P2 & $1,69 \pm 0,13^{\mathrm{a}}$ \\
\hline 4. & P3 & $1,63 \pm 0,12^{\mathrm{a}}$ \\
\hline 5. & P4 & $1,45 \pm 0,07^{\mathrm{b}}$ \\
\hline
\end{tabular}

*= berbeda nyata (a,bsuperskrip yang berbeda pada kolom yang sama menunjukkan perbedaan yang nyata $\mathrm{P}>0,05$ ) 
Agrisaintifika

Jurnal Ilmu-Ilmu Pertanian

Vol. 4, No. 2, 2020

Pemberian daun Ashitaba dalam pakan burung puyuh jantan yang di pelihara selama 2 minggu berpengaruh secara nyata mampu meningkatkan bobot potong $(P>0,05)$. Bobot potong tertinggi dicapai pada level P4 yaitu 152.25 gram. Penelitian yang dilakukan oleh Ratna dkk (2016) menyatakan berat badan puyuh jantan tipe petelur umur 7 minggu adalah 118,78 gram, jika dibandingkan dengan penelitian ini, maka bobot puyuh jantan umur 6 minggu yang diberikan tepung Daun Ashitaba jauh lebih tinggi. Hal ini disebabkan karena adanya kandungan flavonoid dalam tepung daun Ashitaba. Total falavonoid dalam pucuk daun Ashita baberkisar $219 \mathrm{mg} / 100 \mathrm{~g}$ berat basah (Yang et al, 2005). Senyawa aktif flavonoid berperan lagsung sebagai antibiotic dengan mengganggu fungsi dari mikroorganisme seperti bakteri dan virus, membantu dalam membasmi mikroba pathogen didalam saluran pencernaan sehingga zat makanan dapat dimanfaatkan secara efisien sehingga dapat dikonversi menjadi daging (Muiz, 2016). Bobot potong akan menentukan harga jual ternak sehingga mempengaruhi besar kecilnya pendapat peternak .Blakely dan Blade (1991) yang dikutipolehSuryanah, dkk (2016) menyatakan bahwa tingkat konsumsi ransum akan mempengaruhi laju pertumbuhan dan bobot akhir.

Hasil analisis statistic menunjukkan bahwa penambahan tepung daun Ashitaba dalam pakan burung puyuh jantan berpengaruh secara nyata menurunkan angka konversi pakan $(P>0,05)$ konversi pakan terendah didapatkan pada level pemberian P4 yaitu 2\% tepung Daun Ashitaba dengan nilai 1,45. Penelitian yang dilakukan oleh Ratna dkk (2016) menyatakan bahwa nilai konversi ransum puyuh petelur jantan selama 7 minggu sebesar 4,89, serta penelitian yang dilakukan oleh Fransela dkk (2017) menyatakan bahwa konversi pakan burung puyuh yang diberikan keong sawah sebagai pengganti tepung ikan adalah 2,23 sampai 2,14. Berdasarkan perbandingan beberapa hasil penelitian didapatkan hasil konversi pakan dalam penelitian jauh lebih rendah. Siregar (1982) menyatakan bahwa konversi ransum sangat ditentukan oleh konsumsi ransum dan pertambahan bobot badan yang dihasilkan dan semakin baik mutu ransum maka angka konversi pakan semakin kecil.Menurut Lacy dan Vest (2000) yang dikutip oleh Dionysius (2016) yang menyatakan bahwa faktor utama yang mempengaruhi konversi pakan adalah genetik, ventilasi, sanitasi, kulitas pakan, jenis pakan, penggunaan zat aditif, kualitas air, penyakit dan pengobatan serta manajemen pemeliharaan, selain itu meliputi faktor penerangan, pemberian pakan, dan faktor sosial. Konversi pakan digunakan untuk melihat efisiensi penggunaan pakan oleh ternak atau dapat dikatakan efisiensi pengubahan pakan menjadi produk akhir yakni pembentukan daging (Wirapati, 2008 yang dikutip oleh Razak, 2016).

\section{SIMPULAN}

Pemberian tepung Ashitaba dalam susunan ransum burung puyuh jantan Coturnix coturnix japonica fase akhir tidak berpengaruh nyata terhadap jumlah konsumsi pakan dan pertambahan bobot badan, akan tetapi berpengaruh nyata dalam meningkatkan bobot potong serta berpengaruh nyata dalam menurunkan angka konversi pakan.

\section{DAFTAR PUSTAKA}

Anggorodi, R. 1994. Ilmu Makanan Ternak Umum. Penerbit PT. Gramedia Pustaka Utama. Jakarta.

Baba K, Taniguchi M, Shibano M, Minami $\mathrm{H}, 2$ 2009. "The Components and Line Breeding of Angelica keiskei koidzumi 
“. Bunseki Kagaku, Desember, Vol. 58 No.12.

Dionysius A. W. Mone, Edhy Sudjarwo, Muharlien. 2016. Pengaruh Jenis Burung Puyuh (Coturnix coturnix japinica) Dengan Pemberian Pakan Komersil yang Berbeda Terhadap Penampilan Produksi Periode Bertelur. Jurnal Ternak Tropik Vol 17. No2 :43-49. 2016

Fransela.T.C.L.K. Sarajah. M. E. R Montong dan M. Najoan 2017. Performa Burung Puyuh (Coturnix coturnix japonica) Yang Diberikan Tepung Keong Sawah (Pila ampullacea) sebagai Pengganti Tepung Ikan dalam Ransum. Jurnal Zootek.37 (1):62-69.

Geofrin Henry Lase, Endang Sujana dan Heni Indrijani. 2016. Performa Pertumbuhan Puyuh Coturnix coturnix japinica Petelur Betin Silang Warna Bulu Coklatdan Hitam Di Pusat Pembibitan Puyuh Universitas Padjajaran. Universitas Padjajaran. Bandung

Inamori Y, Baba K, Tsujibo H, Taniguchi M, Nakata K, Kozawa M, 1991. "Antibacterial Actifity of Two Chalcones, Xanthoangelol and 4Hydroxyderricin, Isolated from the Root og Angelica keiskei koidzumi". Chemical and Pharmacy Bulletin Osaka University of Pharmaceutical Science. 39(6);1604-5.

Kusriningrum. 2008. Perancangan Percobaan. Airlannga University Press, Surabaya.

Manafe. M. E, M. L. Mullik dan F. M. S. Telupere. 2017. Performa Ayam Broiler melalui Penggunaan Tepung Krokot (Portulaca olaracea $L$ ) yang Disubstitusikan dalam Ransum Komersil. Jurnal Sains Peternakan Indonesia Vol 12 No 4. OktoberDesember 2017.

Maknum Lukluil, Sri Kismiati dan Isna Mangsiah. 2015. Performans Produksi
Burung Puyuh Coturnix coturnix japonica degan Perlakuan Tepung Limbah Penetasan Telur Puyuh. Jurnal-jurnal IImu Peternakan 25 (3): 53-58 ISSN 0852-3681. Fakultas Peternakan UB.

Muiz Abdul. 2016 Pengaruh Penggunaan Tepung Daun Binahong (Andredera cordifollia) (Ten) (Stennis) sebagai Feed Additive Terhadap Kualitas Karkas Ayam Pedaging. J. Agrisains 17 (1) 54-61 April 2016 ISSN 14123657.

Mattjik, A \& Sumertajaya. 2000. Perancangan Percobaan Dengan Aplikasi SAS Dan Minitab, Bogor: IPB Press, Jilid I.

Panda, A. S.R. Rao, and M. Raju. 2009. Phytobiotics, a Natural Growth Promoter. Poultry International, July 2009. Pp:10-11.

Ratna Rina Dewi, Endang Sujana, Asep Anang. 2016. Performa Pertumbuhan Puyuh Coturnix coturnix japonica Jantan Hasil Persilangan Warna Bulu Hitam dan Coklat Umur 0-7 Minggu di Pusat Pembibitan Puyuh Universitas Padjajaran. Fakultas Peternakan Universitas Padjajaran. Bandung

Rasyaf. M. 2004. Peternakan Broiler. PT Kanisius Jogjakarta.

Razak, A. D, Khaerani. K dan Muh Nur Hidayat. 2016. Pertambahan Bobot Badan, Konsumsi Ransum dan Konversi Ransum Ayam Ras Pedaging yang Diberikan Tepung Daun Sirih (Piper Betle Linn) sebagai Imbuhan Pakan. JIP. Jurnal IImu dan Industri Peternakan Vol. 3. NovemberDesember 2016.

Siregar. A. P.,M. Sabrani. dan Soeprawiro 1982. Tekhik Beternak Ayam Pedaging di Indonesia. Cetakan Ke 2. Margie Group. Jakarta.

Steel, R. G. D. Dan J. Torrie. 1993. Prinsip dan Prosedur Statistik suatu Pendekatan Biometrik. Alih Bahasa B. Sumantri. Gramedia. Jakarta. 
Agrisaintifika

Jurnal Ilmu-Ilmu Pertanian

Vol. 4, No. 2, 2020

Oktaviana, et al. 2020

Suryanah, H Nur dan Anggraeni. 2016. Pengaruh Penambahan Neraca Kation Anion Ransum yang Berbeda Terhadap Bobot Karkas dan Bobot Giblet Ayam Broiler. Jurnal Peternakan Nusantara 2 (1):1-8

Wahju, J. 1997. Ilmu Nutrisi Unggas. Cetakan Ke 4 Gadjah Mada University Press. Yogyakarta.

Yang, R., S. Lin dan G. Kuo. 2005. Content and distribution of flavonoids among 91 edible plant species. Asia Pacific J. ClinNutr. 17 : 275-279.

Zuprizal, 2004. Antibiotik, Probiotik dan Fitobiotik dalam Pakan Unggas Ilmiah Populer. Majalah Poultry Indonesia No 284. Jakarta. 